\title{
CYPRIPEDIUM CALCEOLUS (ORCHIDACEAE) IN CENTRAL RUSSIA: A CASE STUDY FOR ITS POPULATIONS IN TWO PROTECTED AREAS IN THE REPUBLIC OF MORDOVIA (RUSSIA)
}

\author{
Anatoliy A. Khapugin ${ }^{1,2,3}$, Gennadiy G. Chugunov ${ }^{1,2}$ \& Elena V. Vargot ${ }^{1,2}$ \\ ${ }^{1}$ Joint Directorate of the Mordovia State Nature Reserve and National Park "Smolny", \\ Dachnyi Lane, 4, Saransk, Republic of Mordovia, 430011, Russia \\ ${ }^{2}$ Mordovia State University, Bolshevistskaya Street, 68, Saransk, Republic of Mordovia, 430005, Russia \\ ${ }^{3}$ Author for correspondence: hapugin88@yandex.ru
}

\begin{abstract}
Cypripedium calceolus is considered as one of the flagship plant species of nature conservation. It is legally protected throughout Eurasia. Due to its wide distribution range, this Eurasian species could be considered as Least Concern, Near Threatened, Vulnerable, Endangered or Critically Endangered taxon. We performed an analysis of the status for some C. calceolus populations in Central Russia located in the Republic of Mordovia, with emphasis on populations situated in the federal protected areas. The aim of our study was to asses the modern state and the endangerment of $C$. calceolus populations. The environment conditions and species composition in five habitats with rare species in Mordovia were compared using phytoindication methods. Changes in stage spectrum and total abundance dynamics in C. calceolus populations over 2011-2016 were estimated and compared with available data from other locations within species' range. Reproductive ability of populations from the federal protected area, Mordovia State Nature Reserve, were studied. The results showed that $C$. calceolus grows in three habitat types that differed in environment conditions and floristic composition. Convallaria majalis was the only species registered in all studied locations, together with $C$. calceolus. In Central Russia this species occurs in broad-leaved, coniferous and mixed forests. The three populations of C. calceolus within the Mordovia State Nature Reserve and National Park "Smolny" were characterized by the dominance of vegetative individuals in stage spectrum, while generative plants predominated in two other populations located in mixed forests. No correlation between total abundance of individuals and stage spectrum in populations of threatened species has been found over the study period. The population in Mordovia Reserve showed a higher fruit set $(36.7 \%$ as a mean) than others reported within its range. Continued population monitoring of $C$. calceolus in Central Russia from different habitat types is suggested. Generalization of jointly obtained demographic, ecological, phytocoenological data will be appropriate in order to develop measures for conservation and management of C. calceolus habitats.
\end{abstract}

KeY wORDS: stage spectrum, critically endangered species, Cypripedium calceolus, fruit set, plant population, protected areas

Introduction. The orchid family is one of the most species rich families of seed plants. It includes about 880 genera with more than 25,000 species in the world (Cribb et al. 2003). Due to mycorrhizal specificity (McCormick \& Jacquemyn 2014), pollinator specialization (Cozzolino \& Widmer 2005) and limited germination rates (Dearnaley et al. 2012), most orchids are extremely susceptible to habitat disturbance as compared to other plants (Cozzolino \& Widmer 2005, Jacquemyn et al. 2007). Orchids frequently occur in very specific habitats (Wotavova et al. 2004). They are particularly vulnerable to climate and land-cover changes due to their narrow ecological preferences. A high proportion of species have declined in abundance and are considered to be rare, threatened, or endangered, primarily as a result of habitat loss (Kull \& Hutchings 2006, Pillon \& Chase 2007). Patterns of orchid richness are regulated by habitat size and elevation range at large scales (Acharya et al. 2011), while by light availability, soil moisture, canopy height and area (especially for the epiphytic orchids) at fine scales (McCormick \& Jacquemyn 2014). 
About 130 orchid species belonging to 42 genera are documented in the Russian Federation (Varlygina 2011). Due to the increase of anthropogenic influence and natural features of orchid species many of these plants are endangered and 65 species were included in the Red Data Book of the Russian Federation (Bardunov \& Novikov 2008). There are 39 orchid species belonging to 20 genera in Central Russia (Averyanov 2014). Of these, 19 species were included in the Red Data Book of Russian Federation (Bardunov \& Novikov 2008).

Cypripedium calceolus L. is one of the most attractive terrestrial representatives of Orchidaceae in Eurasia. Its distribution ranges from Great Britain and Scandinavia across Northern and Central Europe to North-Eastern Spain, Northern Italy, and from Western Europe through southern Siberia to Rebun Island (Bardunov \& Novikov 2008, Cribb 1997, Hultén \& Fries 1986, Kull 1999, Vakhrameeva et al. 2014). Although, C. calceolus is included in the Global IUCN Red List with category Least Concern (LC), this is one of the most endangered orchid species in Europe (Kull 1999). In different regions of Eurasia, C. calceolus has been estimated as Near Threatened (Bilz 2011, Turis et al. 2014), Vulnerable (Rassi et al. 2001), Endangered (Witkowski et al. 2003), and Critically Endangered (Blinova \& Uotila 2011, Khapugin et al. 2017a, Khapugin et al. 2017c). International studies on C. calceolus related to its genetic diversity (Brzosko et al. 2009, Brzosko et al. 2011, Fay et al. 2009, Kḷavina et al. 2014, Minasiewicz \& Znaniecka 2014), population ecology and biology (Blinova 2002, Brzosko 2002, Davison et al. 2013, Fardeeva et al. 2010, Gajewski \& Marcisz 2014, Khapugin et al. 2014, Korczyński \& Krasicka-Korczyńska 2014, García et al. 2002, García et al. 2010, Gorchakovskii \& Igosheva 2003, Kirillova 2015, Kull 1998, Nicolè et al. 2005, Puchnina 2017, Stetsuk 2013, Zheleznaya 2015), impacts of environment conditions and stress-factors on the species (Blinova 2002, 2012, Czerepko et al. 2014, Kirillova 2016, Kirillova et al. 2012, Puchnina 2017, Shefferson et al. 2012), pollination (Antonelli et al. 2009, Tremblay 1994), as well as the list of publications with new records of this threatened species is continuously enlarging (e.g. Balázs et al. 2016, Matysek et al. 2014, Piwowarski 2013, Puchnina et al. 2015, Randić et al. 2013). However, there is a lack of data on the status of
C. calceolus populations in many parts of its natural distribution range.

Cypripedium calceolus is included in the Red Data Book of the Russian Federation (Bardunov \& Novikov 2008). It is known from 20 populations in the Republic of Mordovia (Central Russia). However, 14 sites are located outside of the existing protected areas network (Khapugin et al. 2017b). Moreover, actual protection of C. calceolus is provided only for three populations in the Mordovia State Nature Reserve. Thus, the status of other populations still needs to be monitored in order to understand what factors could contribute to deplete the $C$. calceolus populations there.

Cypripedium calceolus is an emblematic plant species in the Republic of Mordovia. Its picture has been portrayed on the cover page of $1^{\text {st }}$ edition of the Red Data Book of the Republic of Mordovia (plants, fungi, lichens) (Silaeva 2003). Recently, the regional IUCN status of this species was estimated as Critically Endangered (Khapugin et al. 2017a,c). However, data on individual populations are fragmented. Continuous six-year studies have been carried out only in the Mordovia State Nature Reserve. Two local C. calceolus populations at the boundary of the National Park "Smolny" have been studied for three years. In addition, fragmentary data of different years on two more C. calceolus populations in Bolshie Berezniki district of Mordovia, are available. But to date these fragmented data were not generalized.

The aim of the present study was to study population structure, biology and ecology of C. calceolus in Central Russia, emphasizing its populations in two federal Protected Areas in the Republic of Mordovia: Mordovia State Nature Reserve and National Park "Smolny". The following questions were addressed: (I) What is the status of C. calceolus populations protected by Mordovia State Nature Reserve and National Park "Smolny"? (II) Are there differences between the C. calceolus populations studied?

Materials and methods. The Republic of Mordovia is located on the border of the forest and forest-steppe zones in Central Russia. The eastern part of the Republic of Mordovia covers the north-west of the Volga Upland, and its western part is located on the west of the Oka-Don lowland. High habitat diversity is observed, coniferous and mixed forests are distributed 
in the west and north-west, broad-leaved forests are distributed in the central and eastern parts, and foreststeppe landscapes dominate in the east and south-east (Yamashkin 1998, 2012).

Cypripedium calceolus is a long-lived perennial that may survive more than 30 years (Kull 1988). This is a geophyte with a horizontal rhizome growing up to $10 \mathrm{~cm}$ underground. Stems are $20-60 \mathrm{~cm}$ in height with 3-5 elliptical to ovate-oblong leaves, which are $11-17 \mathrm{~cm}$ long and 5.5-8 $\mathrm{cm}$ wide. It produces one or two (rarely three) large flowers, with a purple-brown perianth and yellow shoe-shaped labellum. The fruit is a capsule ( $3 \mathrm{~cm}$ long and about $0.9 \mathrm{~cm}$ in diameter) with 6,000-17,000 seeds (Denisova \& Vakhrameeva 1978, Tatarenko 1996, Kull 1999).

Most well-studied populations of C.calceolus in the Republic of Mordovia are located in the Mordovia State Nature Reserve (MR), National Park "Smolny" (NP) and in the vicinity of the biological station of the Mordovia State University (BS). Of the three populations in MR, only one is still known. One population has disappeared after a wildfire in 2010, while a second population is very small (up to 10 individuals) and does not appear every year. Results of populationbased studies in the Mordovia State Nature Reserve (MR) and in National Park "Smolny" (NP) were compared. Data for the populations' stage structure and floristic composition in the vicinity of the biological station of the Mordovia State University (BS1: about $750 \mathrm{~m}^{2}, 54.188541 \mathrm{~N}, 46.172314 \mathrm{E}$; BS2: about $\left.350 \mathrm{~m}^{2}, 54.183617 \mathrm{~N}, 46.175930 \mathrm{E}\right)$ were available from 2012 and 2015. The field investigations were carried out for the populations in MR (about 1000 $\mathrm{m}^{2}, 54.716110 \mathrm{~N}, 43.205170 \mathrm{E}$ ) in 2011-2016, for population NPt near Tashkino village in 2014-2016 (about $100 \mathrm{~m}^{2}, 54.736807 \mathrm{~N}, 45.505268 \mathrm{E}$ ), and for the population NPk near Kamchatka village during 2012, 2014 and 2016 (about $350 \mathrm{~m}^{2}, 54.726835 \mathrm{~N}$, 45.457555 E).

To get a complete overview of the species' situation, abundance of individuals and morphometric traits of plants of Cypripedium calceolus populations were studied on established square $(1 \times 1 \mathrm{~m})$ plots. In total, three (NPt) and six (NPk, MR) square plots were established in studied habitats. The composition of the accompanying flora was recorded on square plots $(15 \times 15 \mathrm{~m})$ with respect to each location for fur- ther interpretation. The abundance of each species has been estimated in accordance with the scale of BraunBlanquet (1964). The nomenclature is in accordance with The Plant List (2013) and Euro+Med Plantbase (Euro+Med 2006+). Jaccard's similarity index was calculated (Jaccard 1901).

Based on the species composition of flora within each C. calceolus location, the mean environment indicator values (EIVs) for each studied habitat was calculated. For this purpose, Tsyganov's (1983) ecological scale was used, where EIVs are arranged as intervals. Therefore, for each plant species the range of its existence in relation to a concrete factor, for instance, soil nitrogen, moisture etc., can be defined. Values could be evaluated in conventional units covering the total factor range from the minimum up to the maximum in relation to concrete species. Mean values were calculated using an algorithm suggested by Buzuk \& Sozinov (2009). Six environmental factors were examined: shadiness (L), temperature (T), continentality (C), moisture (M), $\mathrm{pH}(\mathrm{R})$, and soil nitrogen $(\mathrm{N})$.

In the framework of our study each above-ground shoot was the accounting unit being conditionally treated as an individual. Based on revealed morphometrical data (height of shoot, number of leaves and leaf veins, presence/absence of flowers), individuals of C. calceolus were divided into four ontogenetic stages: juvenile (j), immature (im), mature vegetative (v) (non-flowering adults) and generative (g) (flowering adults) (Denisova \& Vakhrameeva 1978, Vakhrameeva \& Tatarenko 1998). The group of mature vegetative individuals comprised both virginal and generative plants which failed to form generative shoots and, hence, were in the vegetative state in the study year. Depending on the ratio between these age groups, three types of the stage spectra of populations were distinguished according to Gorchakovskii \& Igosheva (2003): vegetatively-oriented (with the prevalence of juvenile, immature, or mature vegetative individuals), generatively-oriented (with the prevalence of generative individuals), and bimodal (with two peaks - one accounted for by vegetative and the other, by generative individuals). Stage spectra of C. calceolus populations at the Republic of Mordovia were compared with results of previous demographic studies carried out in Spain, Estonia, Poland, Central and Northern Russia and Siberia (Fig. 1). 


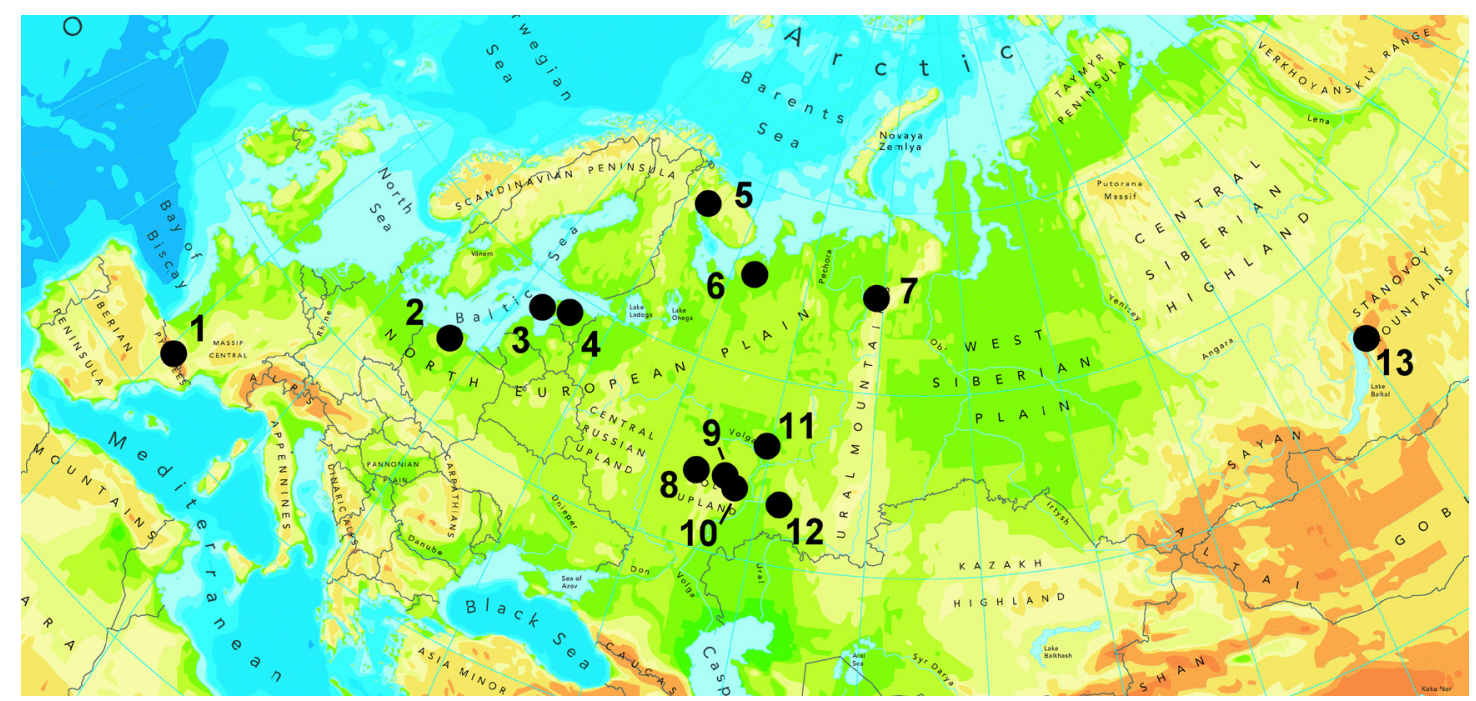

FiguRE 1. Geographical location of some Cypripedium calceolus populations within its range. Locations: 1. Sallent, Pineta,

Tormosa, Ordesa; 2. Lake Kwiecko; 3. Muhu I, Muhu II, Hiiumaa, Puhtu; 4. Ussisoo, Tooma, Õisu I; 5. Apatity; 6. Pinega 1, Pinega 2; 7. "Yugyd va" 1-7; 8. Mordovia State Nature Reserve (MR); 9. neighbourhoods of villages Tashkino (NPt) and Kamchatka (NPk) near National Park "Smolny"; 10. neighbourhood of the biostation of the Mordovia State University (BS1, BS2); 11. Republic of Tatarstan; 12. Buzuluksky Bor; 13. Barguzinsky Reserve. Detail data on each location - in Table 3. Map with modifications from http://www.eea.europa.eu/legal/copyright

In 2014, the C. calceolus population in the Mordovia State Nature Reserve was suggested as the most sustainable in the region. The total number of generative individuals, number of plants with two flowers and the fruit set were investigated in the same population in our study. The sustainability of the population was estimated on the basis of successful reproduction of plants (e.g. Bizoux et al. 2011, Hegazy et al. 2010, Oostermeijer et al. 2003).

Statistical analyses were carried out using PAST 3.15 (Hammer et al. 2001). The ordination techniques, using the principal component analysis (PCA), defined the major gradients in the spatial arrangement of studied habitats of the analyzed dataset. For ecological interpretation of the ordination axes, average environment indicator values were calculated for established plots and were plotted onto the PCA ordination diagram as supplementary environmental data.

Results. The composition of flora accompanying $C$. calceolus was documented in all five locations studied. The list includes 80 species of vascular plants from 69 genera and 37 families (Table 1). Of these, 36 species from 32 genera and 22 families in MR, 15 species from 15 genera and 13 families in NPk, 27 species from 25 genera and 21 families in NPt, 27 species from 26 genera and 16 families in BS1 and 28 species from 27 genera and 20 families in BS2. The Jaccard's similarity index amongst accompanying flora varied from $6.7 \%$ (amongst MR and NPk) to $42.9 \%$ (amongst NPt and NPk) (Table 2).

Cypripedium calceolus inhabited shade or semishade forest communities, where only Convallaria majalis L. was an obligatory component. Four species (Lathyrus vernus (L.) Bernh., Poa nemoralis L., Quercus robur L., Rubus saxatilis L.), were registered in four of the five habitats; and seven species (Aegopodium podagraria $\mathrm{L}$., Carex digitata L., Maianthemum bifolium (L.) F.M. Schmidt, Tilia cordata Mill., Trientalis europaea L., Vaccinium vitis-idaea L., Viola mirabilis $\mathrm{L}$.) were found in three of the five studied sites.

The spatial arrangement of studied locations demonstrated that the MR site clearly separated from all other habitats on the base of higher soil moisture and lower values of soil $\mathrm{pH}$ and light level. Both habitats from the vicinity of Mordovia University biostation (BS1, BS2) are closely located at the PCA-ordination diagram due to their close geographical position. Consequently, these habitats have similar environmental conditions (Fig. 2). These three locations 
TABLE 1. List of flora accompanying Cypripedium calceolus in the Republic of Mordovia (Central Russia).

\begin{tabular}{|c|c|c|c|c|c|}
\hline \multirow{2}{*}{ Species } & & & Locations & & \\
\hline & MR & NPk & NPt & BS1 & BS2 \\
\hline Acer platanoides $\mathrm{L}$. & & & + & & \\
\hline Acer tataricum $\mathrm{L}$. & & & & & + \\
\hline Actaea spicata L. & & & + & & \\
\hline Aegopodium podagraria $\mathrm{L}$. & & + & + & + & \\
\hline Alnus glutinosa (L.) Gaertn. & + & & & & \\
\hline Angelica archangelica L. & & & & & + \\
\hline Antennaria dioica (L.) Gaertn. & & & & & + \\
\hline Asarum europaeum $\mathrm{L}$. & & & + & & \\
\hline Betonica officinalis L. & & & & + & + \\
\hline Betula pendula Roth & & + & & & \\
\hline Brachypodium sylvaticum (Huds.) Beauv. & + & & & & \\
\hline Calamagrostis epigejos (L.) Roth & & & & & + \\
\hline Carex digitata $\mathrm{L}$. & + & + & + & & \\
\hline Carex disperma Dew. & + & & & & \\
\hline Carex Ioliacea L. & + & & & & \\
\hline Carex pilosa Scop. & & & + & & + \\
\hline Epilobium angustifolium $\mathrm{L}$. & + & & & & \\
\hline Circaea alpina $\mathrm{L}$. & + & & & & \\
\hline Cirsium oleraceum (L.) Scop. & & & & + & + \\
\hline Convallaria majalis L. & + & + & + & + & + \\
\hline Corylus avellana $\mathrm{L}$. & & + & + & & \\
\hline Cypripedium calceolus L. & + & + & + & + & + \\
\hline Dryopteris carthusiana (Vill.) H.P. Fuchs & + & & & & \\
\hline Dryopteris cristata (L.) A. Gray & + & & & & \\
\hline Epilobium angustifolium $\mathrm{L}$. & + & & & & \\
\hline Euonymus verrucosa Scop. & & & + & & \\
\hline Festuca gigantea (L.) Vill. & + & & & & \\
\hline Filipendula ulmaria (L.) Maxim. & & & & + & + \\
\hline Fragaria vesca L. & + & & & & + \\
\hline Frangula alnus Mill. & + & & & & + \\
\hline Galium palustre $\mathrm{L}$. & + & & & & \\
\hline Galium spurium L. & & & & + & \\
\hline Geum urbanum L. & & & + & & \\
\hline Glechoma hederacea L. & & & + & & \\
\hline Gymnocarpium dryopteris (L.) Newm. & + & & & & \\
\hline Heracleum sibiricum L. & & & & + & \\
\hline Hieracium umbellatum $\mathrm{L}$. & & & & + & \\
\hline Impatiens noli-tangere L. & & & & & + \\
\hline
\end{tabular}


TABLE 1 (continues).

\begin{tabular}{|c|c|c|c|c|c|}
\hline \multirow{2}{*}{ Species } & & & Locations & & \\
\hline & MR & NPk & NPt & BS1 & BS2 \\
\hline Lathyrus pratensis $\mathrm{L}$. & & & & + & \\
\hline Lathyrus vernus (L.) Bernh. & & + & + & + & + \\
\hline Linnaea borealis L. & + & & & & \\
\hline Lonicera xylosteum L. & + & & & & \\
\hline Luzula pilosa (L.) Willd. & + & & & & \\
\hline Lysimachia vulgaris $\mathrm{L}$. & + & & & + & \\
\hline Majanthemum bifoliun (L.) F. M. Schmidt & + & & + & + & \\
\hline Melampyrum nemorosum $\mathrm{L}$. & & & & + & + \\
\hline Melampyrum pratense $\mathrm{L}$. & & & & & + \\
\hline Melica nutans L. & & & & + & \\
\hline Mercurialis perennis $\mathrm{L}$. & & & + & & \\
\hline Milium effusum $\mathrm{L}$. & & & & + & + \\
\hline Orthilia secunda (L.) House & + & & & & \\
\hline Oxalis acetosella L. & + & & & & \\
\hline Padus avium Mill. & + & & & & \\
\hline Paris quadrifolia $\mathrm{L}$. & + & & & + & \\
\hline Picea abies (L.) Karst. & + & & & & \\
\hline Pinus sylvestris $\mathrm{L}$. & + & & & + & + \\
\hline Poa nemoralis $\mathrm{L}$. & & + & + & + & + \\
\hline Populus tremula $\mathrm{L}$. & & + & + & & \\
\hline Potentilla erecta (L.) Raeusch. & & & & + & \\
\hline Pteridium aquilinum (L.) Kuhn & & & & + & \\
\hline Pulmonaria obscura Dumort. & & & + & & \\
\hline Pyrola rotundifolia L. & & & & + & + \\
\hline Quercus robur $\mathrm{L}$. & + & + & + & & + \\
\hline Ranunculus auricomus L. & & & + & & \\
\hline Rhamnus cathartica L. & & + & + & & \\
\hline Rubus caesius $\mathrm{L}$. & & + & + & & \\
\hline Rubus saxatilis L. & + & & + & + & + \\
\hline Solanum dulcamara L. & + & & & & \\
\hline Sorbus aucuparia L. & & + & + & & \\
\hline Stellaria holostea L. & + & & + & & \\
\hline Tilia cordata Mill. & & + & + & & + \\
\hline Trientalis europaea L. & + & & & + & + \\
\hline Trifolium pratense $\mathrm{L}$. & & & & + & \\
\hline Vaccinium myrtillus $\mathrm{L}$. & + & & & & \\
\hline Vaccinium vitis-idaea L. & + & & & + & + \\
\hline Veronica chamaedrys L. & & & & & + \\
\hline
\end{tabular}


TABLE 1 (continues).

\begin{tabular}{l|c|c|c|c|c}
\hline \multicolumn{1}{r|}{ Species } & & & Locations & \\
\cline { 2 - 6 } & MR & NPk & NPt & BS1 & BS2 \\
\hline Viburnum opulus L. & + & & & + \\
\hline Vicia sylvatica L. & & & & + & \\
\hline Viola mirabilis L. & & + & + & & + \\
\hline Viola palustris L. & & & & & + \\
\hline Viscaria vulgaris Bernh. & 36 & 15 & 27 & 27 & 28 \\
\hline IN TOTAL: & & & & & \\
\hline
\end{tabular}

(MR, BS1, BS2) are well separated from the NPk and NPt sites on the basis of low values of soil nitrogen, soil $\mathrm{pH}$ and light level. The NPk and NPt sites are closely located at the PCA-ordination diagram. The same picture is obtained for BS1 and BS2 sites. Revealed data obtained using phytoindication method (Fig. 1) are very similar to the results found using Jaccard's similarity index (Table 2).

The stage spectrum in C. calceolus populations in Mordovia was presented by four ontogenetic stages (Fig. 3). Due to the poor and random demographic data from populations in both the BS1 and BS2 sites, these have been excluded from analysis.

Vegetative (juvenile + immature + mature vegetative) individuals dominated in the stage structure of $C$. calceolus populations during the study period (Fig. 2). Therefore, these populations could be considered as vegetatively-oriented. However, in certain years some fluctuations were recorded, allowing interpreting these populations as moderate or even generatively-oriented: NPk population in 2012, NPt population in 2014 or MR population in 2016. In contrast, fragmentary demographic data on both BS1 and BS2 populations showed dominance or equality of generative individuals in stage spectra (Khapugin et al. 2014).

TABle 2. Compositional similarity (Jaccard's index, 100

$\times \mathrm{J})$ of the accompanying flora in five locations with Cypripedium calceolus in the Republic of Mordovia (Central Russia).

\begin{tabular}{l|l|l|l|l}
\hline & NPk & BS2 & BS1 & MR \\
\hline NPt & \multirow{2}{*}{42.9} & 14.9 & 15.2 & 8.8 \\
NPk & & 11.1 & 14.7 & 6.7 \\
\hline BS2 & & & 29.3 & 14.8 \\
\hline BS1 & & & & 15.1 \\
\hline
\end{tabular}

We estimated the reproductive ability of $C$. calceolus in the most sustainable population in Mordovia based on a number of two-flowered generative individuals and fruit set in the population (Fig. 4). We found that the percentage of plants with two flowers varied from $0.0 \%$ in 2015 to $16.7 \%$ in 2016 . And there was no correlation of this parameter neither with the number of generative plants in a population nor with the percentage of two-flowered individuals there. Similarly, we didn't find a correlation of these parameters with values of fruit set in the MR population during the study period. It varied from $27.8 \%$ in 2016 to $46.7 \%$ in 2012 .

Discussion. The accompanying flora in the studied sites was similar. In accordance with both PCA-analysis and Jaccard's similarity index, the most significant similarity was found for NPt vs. NPk and BS1 vs. BS2 respectively. These results can be explained by similar environment conditions in these habitats. At the same time, three types of plant communities were defined, demonstrating the ecological variability of $C$. calceolus due to its inhabitation in boreal (MR), steppefied nemoral (NPt, NPk) and mixed (BS1, BS2) forest communities. Unfortunately, there is no record of $C$. calceolus in grassland habitats in the Republic of Mordovia. Similar results shown using the Jaccard similarity index and phytoindication methods allow us to propose their conjoint use for other plant species as it was tested earlier (e.g. Couto et al. 2016, Khapugin et al. 2016, Khapugin 2017, Michálková 2007).

Cypripedium calceolus populations protected by Mordovia State Nature Reserve and National Park "Smolny" could be considered as vegetatively-oriented. However, the portion of generative individuals was significant over the whole study period varying from $31.3 \%$ in NPk to $39.2 \%$ in MR. Generative plants 
FIgURE 2. Principal component analysis (PCA) ordination diagram of habitats with Cypripedium calceolus in the Republic of Mordovia (Central Russia) based on mean environmental indicator values. Designations: L. shadiness, T. temperature, C. continentality, M. soil moisture, R. soil pH, N. soil nitrogen. To reveal ecological gradients the mean environmental indicator values were plotted onto PCA-ordination diagram as supplementary environmental variables.

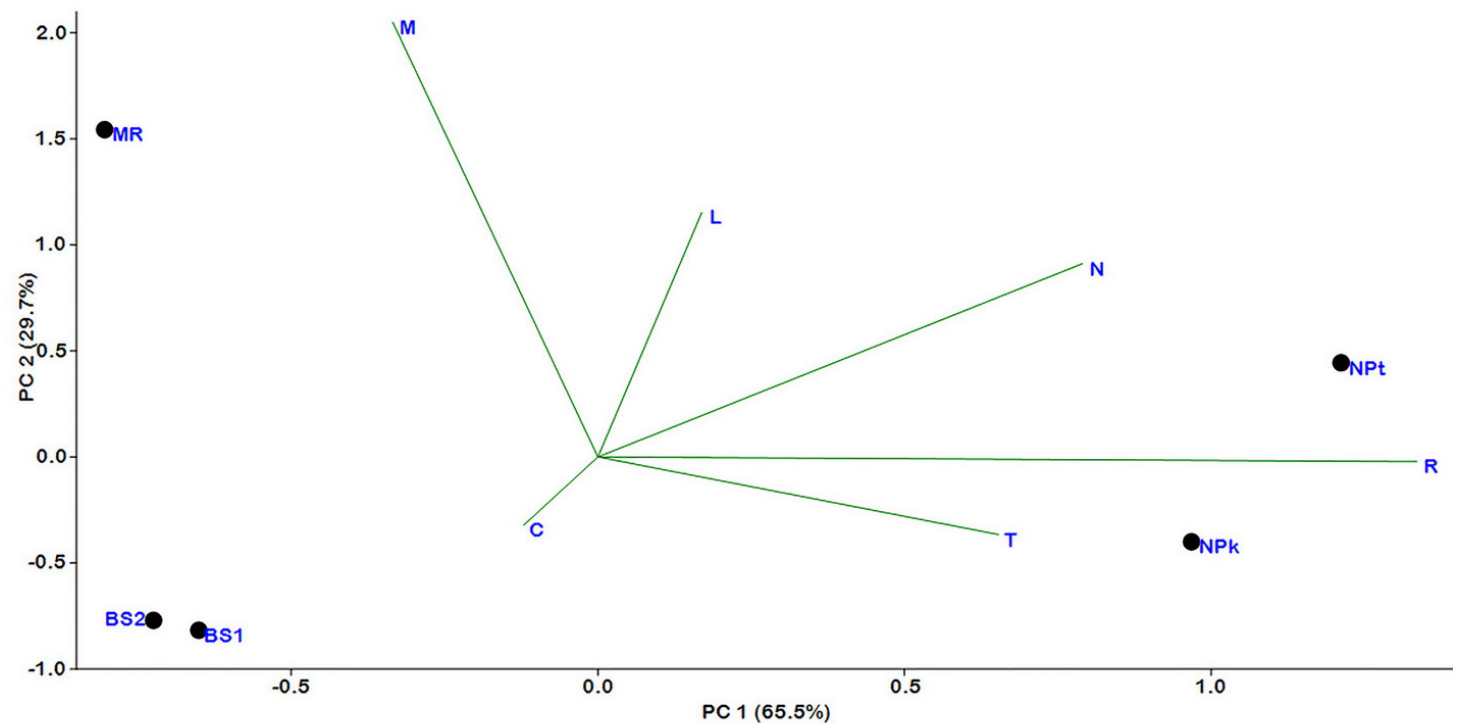

had dominated in different time periods of the study in these habitats, even though there are some populations characterized by the dominance of generative plants in the region. On the basis of previous studies (Khapugin et al. 2014), with additions (Table 3), both populations BS1 and BS2 had generatively-oriented stage spectra. The total abundance of individuals in a population did not affect its stage spectrum structure. For instance, a general low decrease of total abundance in MR population led to the dominance of generative individuals in 2016, while the general increase of individuals' number in the NPk population led to the dominance of vegetative individuals in the same year. These results are consistent with data of Kull (2003) who suggested that neither short-term nor long-term studies of $C$. calceolus populations could show any clear trends in their stage spectrum structure due to the effect of annual fluctuations in abundance of individuals. The author also proposed that a large percentage of juvenile plants could be considered as a good indicator of a vital population, and that the population with few juvenile plants may persist, as long as the habitat conditions are suitable if vegetative reproduction in the population is significant and a number of generative individuals is not too low (Kull 2003). Most C. cal- ceolus populations were estimated as vegetatively-oriented in different locations within its range (Table 3). Of all compiled data, the populations located at open or semi-open habitats are characterized by dominance or equality of generative individuals in stage spectra. For instance, these are semi-shade and grassland habitats in locations Sallent and Pineta in Spain Pyrenees (García et al. 2010), the edge of the spruce-larch forest in the National Park "Yugyd va" (Kirillova 2015), populations BS1 and BS2 in Mordovia (Khapugin et al. 2014, with additions). Light level may perhaps be one of the factors determining the stage spectrum of $C$. calceolus populations.

Among all studied populations in Mordovia, only the MR population could be considered as such a population with low but persisting number of juveniles, active vegetative reproduction and the appropriate number of generative individuals. Thus, this population may be considered as the most sustainable. However, an increase of red squirrel (Sciurus vulgaris Linnaeus, 1758) abundance in MR habitat in recent years led to increasing of young Picea abies abundance in the shrub layer. Thus, conditions of special protection regime could lead to the decrease of $C$. calceolus population vitality (Kull 2003). Hence, a further decline in 



FIGURE 3. Structure of stage spectra in Cypripedium calceolus populations (locations MR, NPk, NPt) in the Republic of Mordovia (Central Russia). Ontogenetic stages of individuals: juvenile (j), immature (im), mature vegetative (v), generative $(\mathrm{g})$. 
TABLE 3. Lady's Slipper (Cypripedium calceolus) locations and habitats where age spectra were estimated

\begin{tabular}{|c|c|c|c|c|c|c|}
\hline \multirow[t]{2}{*}{ Location } & \multirow[t]{2}{*}{ Population habitat $^{a}$} & \multicolumn{4}{|c|}{$\begin{array}{l}\text { Percent of individuals of } \\
\text { each age class, } \%\end{array}$} & \multirow[t]{2}{*}{ Reference } \\
\hline & & $j$ & $i m$ & $v$ & $g$ & \\
\hline \multicolumn{7}{|c|}{ Data on incomplete age structure of populations } \\
\hline Sallent ${ }^{b}$ & Forest & - & - & - & 23 & García et al. 2010 \\
\hline Sallent ${ }^{b}$ & Semishade & - & - & - & 49 & García et al. 2010 \\
\hline Sallent ${ }^{b}$ & Grassland & - & - & - & 60 & García et al. 2010 \\
\hline Pineta $^{\mathrm{b}}$ & Forest & - & - & - & 12 & García et al. 2010 \\
\hline Pineta $^{\mathrm{b}}$ & Semishade & - & - & - & 58 & García et al. 2010 \\
\hline Tormosa $^{b}$ & Grassland & - & - & - & 66 & García et al. 2010 \\
\hline Ordesa $^{b}$ & Forest & - & - & - & 0 & García et al. 2010 \\
\hline Lake Kwiecko & Floodplain forest & 2.1 & - & - & 7.8 & $\begin{array}{l}\text { Korczyński \& Śpiewakowski 1991, } \\
\text { Korczyński \& Krasicka-Korczyńska } 2014\end{array}$ \\
\hline Ussisoo & Boreo-nemoral spruce forest & 1.7 & - & - & - & Kull 2003 \\
\hline Tooma & Drained marshy forest & 2.2 & - & - & - & Kull 2003 \\
\hline Muhu I & Wooded meadow & 7.5 & - & - & - & Kull 2003 \\
\hline Muhu II & Alvar forest & 5.7 & - & - & - & Kull 2003 \\
\hline Õisu I & Drained marshy forest & 31.5 & - & - & - & Kull 2003 \\
\hline Hiiumaa & Coastal alvar forest & 39.0 & - & - & - & Kull 2003 \\
\hline Puhtu & Nemoral forest & 2.9 & - & - & - & Kull 2003 \\
\hline
\end{tabular}

\begin{tabular}{|c|c|c|c|c|c|c|}
\hline \multicolumn{7}{|c|}{ Data on complete age structure of populations } \\
\hline Apatity ${ }^{b}$ & Pine forest & 1.9 & 15.4 & 74.1 & 8.4 & Blinova 2002 \\
\hline Republic of Tatarstan & Forests & 2.0 & 8.5 & 37.0 & 52.5 & Fardeeva et al. 2010 \\
\hline "Yugyd va" 1 & Slope covered by larch & 3.7 & 17.5 & 51.0 & 27.9 & Kirillova 2015 \\
\hline "Yugyd va" 2 & Former gold mining site & 8.9 & 16.4 & 28.0 & 46.7 & Kirillova 2015 \\
\hline "Yugyd va" 3 & Shrub-lichen communities on the rocks & 2.5 & 18.0 & 67.3 & 12.2 & Kirillova 2015 \\
\hline "Yugyd va" 4 & Willow stand on the rocks & 1.0 & 8.5 & 37.9 & 52.6 & Kirillova 2015 \\
\hline "Yugyd va" 5 & Fir-spruce grass forest & 4.7 & 9.2 & 34.7 & 51.4 & Kirillova 2015 \\
\hline "Yugyd va" 6 & Edge of the spruce-larch forest & 1.2 & 6.2 & 19.3 & 73.3 & Kirillova 2015 \\
\hline "Yugyd va" 7 & The yernik on the rocks & 6.7 & 46.7 & 26.7 & 20.0 & Kirillova 2015 \\
\hline Buzuluksky Bor & Mixed forests & 6.1 & 13.6 & 40.2 & 40.2 & Stetsuk 2013 \\
\hline Barguzinsky Reserve 1 & Pine forest & 0.0 & 14.3 & 35.7 & 50.0 & Zheleznaya 2015 \\
\hline Barguzinsky Reserve 2 & Mixed (Pinus sibirica $+P$. sylvestris) forest & 3.9 & 27.5 & 19.6 & 49.0 & Zheleznaya 2015 \\
\hline Barguzinsky Reserve 3 & Spruce forest with aspen & 5.6 & 16.7 & 27.8 & 50.0 & Zheleznaya 2015 \\
\hline Pinega 1 & Spruce forest & 0.2 & 7.4 & 48.4 & 44.0 & Puchnina 2017 \\
\hline Pinega 2 & Larch forest & 13.1 & 41.7 & 26.7 & 18.5 & Puchnina 2017 \\
\hline MR & Spruce-pine forest & 1.4 & 10.3 & 49.1 & 39.2 & This study \\
\hline NPt & Broad-leaved forest & 1.9 & 10.8 & 54.1 & 33.2 & This study \\
\hline NPk & Broad-leaved forest & 0.0 & 8.7 & 60.0 & 31.3 & This study \\
\hline $\mathrm{BS} 1$ & Open glade in the pine forest & 0.0 & 1.3 & 40.1 & 58.6 & Khapugin et al. 2014 with additions \\
\hline BS2 & Pine forest at the mire edge & 0.0 & 0.0 & 43.3 & 56.7 & Khapugin et al. 2014 with additions \\
\hline
\end{tabular}

${ }^{a}$ We use the names of habitats referred in relevant publications

b Populations on the limit of species range

Age classes: $j$-juvenile, im - immature, $v$-mature vegetative, $g$-generative.

LANKESTERIANA 17(3). 2017. (C) Universidad de Costa Rica, 2017. 
FIGURE 4. Parameters of reproductive ability of MR population of Cypripedium calceolus in the Republic of Mordovia (Central Russia).

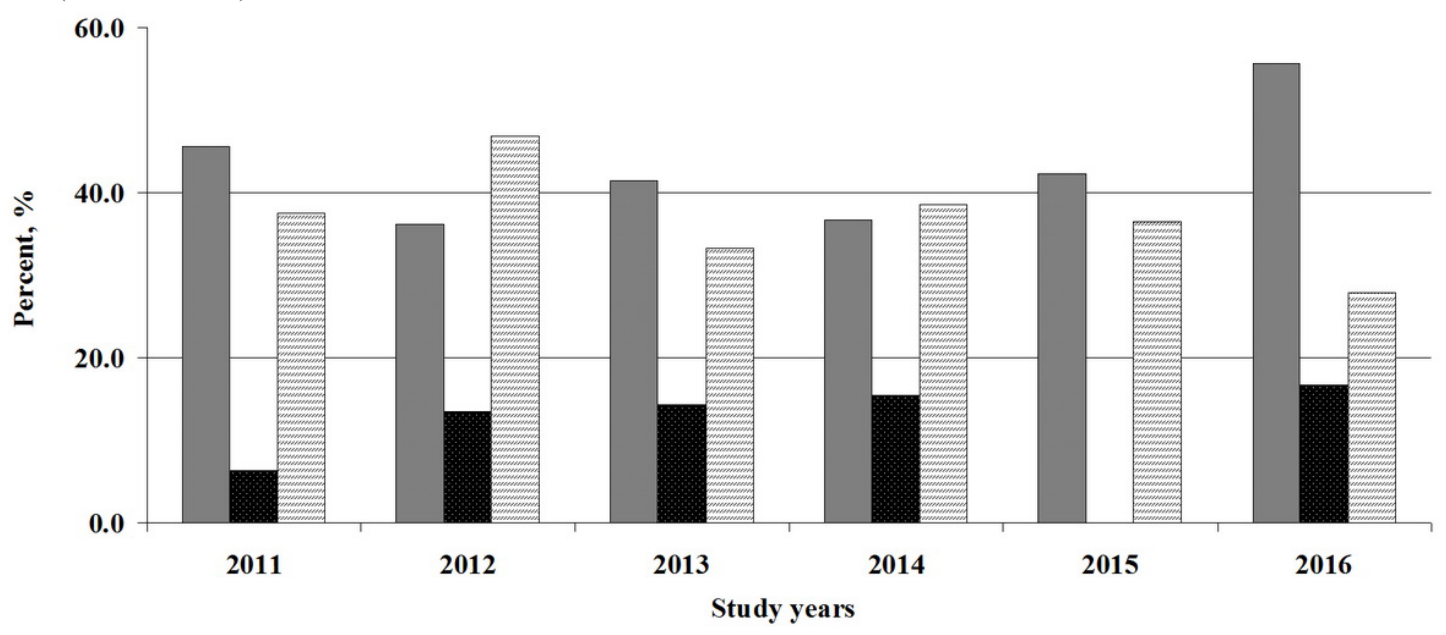

$\square$ Percent of generative plants in population

圆 Percent of two-flower plants among generative individuals

Fruit set

vitality of MR population can be expected in next 1020 years, if this tendency remains. Also, extremely low numbers of immature plants and a lack of juveniles in both BS1 and BS2 populations could be a result of low seed reproduction. It could be considered as a threat to their survival and existence.

Data on the reproductive ability of MR population showed the relatively low number of two-flower plants in comparison to some populations in other parts of species' range (Kull 1995, Stetsuk 2013). Fruit-set has been estimated by various authors, it varies considerably throughout species' range. Levels of fruit set were $33-57 \%$ in Belorussia (Stavrovskaya 1984), 4-14\% in the Moscow district (Varlygina \& Matsenko 1986), 0-25\% (7.7\% mean over four locations and four years) in Sweden (Nilsson 1979), 11\% in Estonia (Kull 1998), 6.8\% in Buzuluksky Bor National Park (Stetsuk 2013). Korczyński \& KrasickaKorczyńska (2014) found that "in 2013, out of 24 blooming stems 8 fruits were set" in the population near the Lake Kwiecko, without indicating of flowers number at blooming stems. However, the fruit set shown in MR population $(36.7 \%$ as a mean over study period) was higher than, for instance, in Estonia (Kull 1998), Sweden (Nilsson 1979), the Moscow region of Russia (Varlygina \& Matsenko 1986), Buzuluksky Bor National Park (Stetsuk 2013) and Lake Kwiecko in West Pomerania (Korczyński \&
Krasicka-Korczyńska 2014). The values of fruit set are comparable only with data from Belorussia (Stavrovskaya 1984). As this species is considered as pollinator-limited in some locations (Brzosko et al. 2017, Kull 1998, Nilsson 1979), higher values of the fruit set in comparison with other available data could be explained as a result of presence of habitats suitable for pollinators (wild bees Andrena) in this location. It is in contrast to other studied locations in Mordovia (Fig. 3, Table 3), where percentage of immature and juvenile individuals was extremely low or these were absent.

Conclusions. Our results demonstrate that C. calceolus in the Republic of Mordovia (Central Russia) shows wide ecological variability. Its presence is confined in diverse habitat types: broad-leaved forests, coniferous forests and mixed forests. We suggest the definition of at least one more habitat (pure grassland (see García et al. 2010)) within the range of this species. Based on the comparison of stage spectra of $C$. calceolus populations both in Mordovia and in other locations within its native range, MR population could be considered as most sustainable and stable in the region due to annually observed juvenile plants, with high percent of mature vegetative and generative individuals in population stage spectrum. Almost annually observed juveniles could be a result 
of relatively high fruit set found for the population in compared with other available data throughout the whole distribution range of $C$. calceolus. However, the overgrowth of woody species during natural succession may have a negative impact on the population (Czerepko et al. 2014, Kull 2003, Nicolè et al. 2005). Thus, we can declare on the higher significance of habitat conservation than individual conservation for protection of C. calceolus.

In order to better understand the environmental preferences of $C$. calceolus, we suggest continue dmonitoring and assessment of its population in Central Russia. The metadata allows us to assume that generalization of jointly obtained demographic, ecological, phytocoenological data will be appropriate for successful conservation and management of $C$. calceolus.

Acknowledgements. We are grateful to S. Suresh Ramanan (Kerala Agricultural University, India) for discussion and proofreading of the manuscript. We are grateful to two anonymous reviewers for their constructive comments and feedback on an earlier version of this paper.

\section{LITERATURE CITED}

Acharya, K. P., Vetaas, O. R. \& Birks, H. J. B. (2011). Orchid species richness along Himalayan elevational gradients. Journal of Biogeography, 38, 1821-1833. doi: 10.1111/j.1365-2699.2011.02511.x

Antonelli, A., Dahlberg, C. J., Carlgren, K. H. I. \& Aplleqvist, T. (2009). Pollination of the Lady's slipper orchid (Cypripedium calceolus) in Scandinavia- taxonomic and conservational aspect. Nordic Journal of Botany, 27, 266-273. DOI: 10.1111/j.1756-1051.2009.00263.x

Averyanov, L. V. (2014). Orchidaceae Juss. - Orchids. In: Flora of Center of European part of Russia. Vol. 11 (pp. 469-480). Moscow: KMK Scientific Press Ltd. (In Russian)

Balázs, Z. R., Roman, A., Balazs, H. E., Căpraş D. \& Podar, D. (2016). Rediscovery of Cypripedium calceolus L. in the vicinity of Cluj-Napoca (Romania) after 80 years. Contribuţii Botanice, 51, 43-53.

Bardunov, L. V. \& Novikov, V. S. (Eds.) (2008). Red Book of Russian Federation (plants and fungi). Moscow: KMK Scientific Press Ltd. (In Russian)

Bilz, M. (2011). Cypripedium calceolus. In: The IUCN Red List of Threatened Species 2011: e.T162021A5532694. Downloaded on 02 July 2017.

Bizoux, J.-P., Cristofoli, S., Piqueray, J. \& Mahy, G. (2011). Conservation of an endemic metallophyte species: Effect of population history and vegetative density on the reproductive success of Viola calaminaria. Journal for Nature Conservation, 19(2), 72-78. DOI: 10.1016/j.jnc.2010.06.002

Blinova, I. (2002). A Northernmost Population of Cypripedium calceolus L. (Orchidaceae): Demography, Flowering, and Pollination. Selbyana, 23(1), 111-120.

Blinova, I. V. (2012). Intra- and Interspecific Morphological Variation of Some European Terrestrial Orchids along a Latitudinal Gradient. Russian Journal of Ecology, 43(2), 111-116. DOI: 10.1134/S1067413612020051

Blinova, I. V. \& Uotila, P. (2011). Chamorchis alpina and Epipactis helleborine in the Murmansk Region, Russia, and assessments of the orchids in the Region using the IUCN Red List Categories. Memoranda Societatis pro Fauna et Flora Fennica, 87, 21-28.

Braun-Blanquet, J. (1964). Pflanzensoziologie. Grundzüge der Vegetationskunde. 3 Aufl. Wien \& New York: Springer.

Brzosko, E. (2002). Dynamics of island populations of Cypripedium calceolus in the Biebrza river valley (northeast Poland). Botanical Journal of the Linnean Society, 139. 67-77. DOI: 10.1046/j.1095-8339.2002.00049.x

Brzosko, E., Wróblewska, A., Ratkiewicz, M., Till-Bottraud, I., Nicole, F. \& Baranowska, U. (2009). Genetic diversity of Cypripedium calceolus at the edge and in the centre of its range in Europe. Annales Botanici Fennici, 46, 201-214. DOI: 10.5735/085.046.0303

Brzosko, E., Wróblewska, A., Tałałaj, I. \& Wasilewska, E. (2011). Genetic Diversity of Cypripedium Calceolus in Poland. Plant Systematics and Evolution, 295, 83-96. DOI: 10.1007/s00606-011-0464-9

Brzosko, E, Ostrowiecka, B, Mirski, P, Jermakowicz, E, Tałałaj, I \& Wróblewska, A. (2017). Pollinator limitation affects low reproductive success in populations of nectarless orchid in the Biebrza National Park. Acta Agrobotanica, 70(1), 1706. DOI: $10.5586 /$ aa. 1706

Buzuk, G. N. \& Sozinov, O. V. (2009). Regression analysis in phytoindication (on example of D.N. Tsyganov's ecological scales). Botany (researches): Proceedings, 37, 356-362. (Minsk: Pravo i ekonomika). (In Russian).

Couto, D. R., Fontana, A. P., Kollmann, L. J. C., Manhães, V. C., Francisco, T. M. \& Cunha, G. M. (2016). Vascular epiphytes in seasonal semideciduous forest in the State of Espírito Santo and the similarity with other seasonal forests in 
Eastern Brazil. Acta Scientiarum. Biological Sciences, 38(2), 169-177. doi: 10.4025/actascibiolsci.v38i2.31320

Cozzolino, S. \& Widmer, A. (2005). Orchid diversity: an evolutionary consequence of deception? Trends in Ecology and Evolution, 20, 487-494. DOI: 10.1016/j.tree.2005.06.004

Cribb, P. (1997). The genus Cypripedium. Royal Botanic Gardens: Kew Botanical Magazine Monograph; Portland, Oregon: Timber Press.

Cribb, P. J., Kell, S. P., Dixon, K. W. \& Barrett, R. L. (2003). Orchid conservation: a global perspective. In: K. W. Dixon, S. P. Kell, R. L. Barrett \& P. J. Cribb (Eds.), Orchid conservation (pp. 1-24). Kota Kinabalu, Sabah: Natural History Publications.

Czerepko, J., Gawryś, R., Cieśla, A. \& Sokołowski, K. (2014). Environment conditions influence on protection status of lady's slipper orchid Cypripedium calceolus L. in managed forests. Sylwan, 158(11), 867-874.

Davison, R., Nicolé, F., Jacquemyn, H. \& Tuljapurkar, S. (2013). Contributions of Covariance: Decomposing the Components of Stochastic Population Growth in Cypripedium calceolus. The American Naturalist, 181(3), 410-420. DOI: $10.1086 / 669155$

Dearnaley, J. D. W., Martos, F. \& Selosse, M. A. (2012). Orchid Mycorrhizas: molecular ecology, physiology, evolution and conservation aspects. In: B. Hock (Ed.), Fungal associations (pp. 207-230). Berlin: Springer.

Denisova, L. V. \& Vakhrameeva, M. G. (1978). Genus Lady's Slipper. Biological flora of Moscow region, 4, 68-70. (Moscow: Publisher of the Moscow State University) (In Russian).

Euro+Med. 2006+. Euro + Med PlantBase - the information resource for Euro-Mediterranean plant diversity. Retrieved from http://ww2.bgbm.org/EuroPlusMed/

Fardeeva, B. M., Chizhikova, N. A. \& Krasilnikova, O. V. (2010). Long-term dynamics of ontogenetic and spatial structure of Cypripedium calceolus L. populations. Scientific notes of the Kazan University, 115(3), 159-173. (In Russian).

Fay, M. F., Bone, R., Cook, P., Kahandawala, I., Greensmith, J., Harris, S., Pedersen, H. Æ., Ingrouille, M. J. \& Lexer, C. (2009). Genetic diversity in Cypripedium calceolus (Orchidaceae) with a focus on north-western Europe, as revealed by plastid DNA length polymorphisms. Annals of Botany, 104(3), 517-525. DOI: 10.1093/aob/mcp116

Gajewski, Z. \& Marcisz, D. (2014). Evaluation of the present condition of the Cypripedium calceolus (Orchidaceae) population in the Ojców National Park. Fragmenta Floristica et Geobotanica Polonica, 21(1), 3-14.

García, M. B., Guzmán, D. \& Goñi, D. (2002). An evaluation of the status of five threatened plant species in the Pyrenees. Biological Conservation, 103, 151-161.

García, M. B., Goñi, D. \& Guzmán, D. (2010). Living at the Edge: Local versus Positional Factors in the Long-Term Population Dynamics of an Endangered Orchid. Conservation Biology, 24(5), 1219-1229. DOI: 10.1111/j.15231739.2010.01466.x

Gorchakovskii, P. L. \& Igosheva, N. I. (2003). Monitoring of Orchid Populations in a Unique Area of Their Concentration in the Middle Urals. Russian Journal of Ecology, 34(6), 363-369. DOI: 10.1023/A:1027373915204

Hammer, Ø., Harper, D. A. T. \& Ryan, P. D. (2001). PAST: Paleontological statistics software package for education and data analysis. Palaeontologia Electronica, 4(1), 9.

Hegazy, A. K., Kabiel, H. F., Boulos, L. \& Sharashy, O. S. (2010). Conservation approach to the demography and dynamics of protected and unprotected populations of the endemic Ebenus armitagei in the Western Mediterranean Coast of Egypt. Journal for Nature Conservation, 18, 151-158. DOI: 10.1016/j.jnc.2009.08.005

Hultén, E. \& Fries, M. (1986). Atlas of North European vascular plants: North of the Tropic of Cancer. Königstein, Federal Republic of Germany: Koeltz Scientific Books.

Jaccard, P. (1901). Étude comparative de la distribution florale dans une portion des Alpes et du Jura. Bulletin de la Societe Vaudoise des Sciences Naturelles, 37, 547-549. (In French).

Jacquemyn, H., Honnay, O. \& Pailler, T. (2007). Range size variation, nestedness and species turnover of orchid species along an altitudinal gradient on Réunion Island: implications for conservation. Biological Conservation, 136, 388-397. DOI: $10.1016 /$ j.biocon.2006.12.008

Khapugin, A. A. (2017). Hieracium sylvularum (Asteraceae) in the Mordovia State Nature Reserve: invasive plant or historical heritage of flora? Nature Conservation Research, 2(4). DOI: 10.24189/ncr.2017.013.

Khapugin, A. A., Chugunov, G. G., Silaeva, T. B. \& Kunaeva, E. N. (2016). Neottianthe cucullata (L.) Schltr. (Orchidaceae Juss.), an endangered orchid in Central Russia. Wulfenia, 23, 189-202.

Khapugin, A. A., Semchuk, A. A., Silaeva, T. B. \& Chugunov, G. G. (2014). Comparative characteristics of populations of Cypripedium calceolus L. (Orchidaceae, Monocotyledones) in the Republic of Mordovia. Povolzhskiy Journal of Ecology, 3, 403-410. (In Russian)

Khapugin, A. A., Silaeva, T. B., Vargot, E. V. \& Chugunov, G. G. (2017a). IUCN guidelines using for assessment of plants 
from the Red Book of Russian Federation at regional level: a case study for the Republic of Mordovia (Russia). Hacquetia, 16(1), 19-33. DOI: 10.1515/hacq-2016-0012

Khapugin, A. A., Chugunov, G. G., Vargot, E. V. \& Silaeva, T. B. (2017b). Vascular plants at the protected areas network of the Republic of Mordovia: present status and prospects. In: S. A. Mukul, A. Z. M. M. Rashid (Eds.), Protected Areas: Policies, Management and Future Directions (pp. 203-231). USA: Nova Science Publishers, Inc.

Khapugin, A. A., Silaeva, T. B., Vargot, E. V., Chugunov, G. G., Grishutkina, G. A., Grishutkin, O. G., Pismarkina, E. V. \& Orlova, Ju. S. (2017c). Estimation of taxa included in the first volume of the Red Data Book of the Republic of Mordovia (Russia) using the IUCN Red List Categories and Criteria. Nature Conservation Research, 2(Suppl. 1), 164-189. DOI: $10.24189 /$ ncr.2017.004

Kirillova, I. A. (2015). Orchids of Subpolar Urals: features of biology and structure of populations. Proceedings of the Komi Science Centre of the Ural Division of the Russian Academy of Sciences, 1(21), 48-54.

Kirillova, I. A. (2016). Phenotypic variability of Cypripedium calceolus L. (Orchidaceae) on its northern distribution bound. Proceedings of the Komi Science Centre of the Ural Division of the Russian Academy of Sciences, 4(28), 46-54.

Kirillova, I. A., Teteryuk, L. V., Pestov, S. V. \& Kirillov, D. V. (2012). Reproduction biology of Cypripedium calceolus (Orchidaceae) in the European North-East of Russia. Botanicheskiy Zhurnal, 97(12), 1516-1532.

Kḷaviņa, D., Grauda, D., Priede, A. \& Rashal, I. (2014). The habitat diversity and genetic variability of Cypripedium calceolus in Latvia. In: Z. Mirek, A. Nikel \& W. Paul (Eds), 6th Europa Planta Conference "Actions for Wild Plants" (Kraków, Poland, 23-27 May 2011) (pp. 91-97). Kraków: Committee on Nature Conservation, Polish Academy of Sciences. DOI: 10.13140/2.1.1101.7601

Korczyński, M. \& Krasicka-Korczyńska, E. (2014). Dynamics of Lady’s slipper orchid (Cypripedium calceolus L.) population at Lake Kwiecko (West Pomerania). Biodiversity: Research and Conservation, 36, 53-60. DOI: 10.2478/biorc-2014-0026

Kull, T. (1988). Identification of clones in Cypripedium calceolus (Orchidaceae). Proceedings of the Estonian Academy of Sciences Biology, 37, 195-199.

Kull, T. (1995). Genet and ramet dynamics of Cypripedium calceolus in different habitats. Abstracta Botanica, 19, 95-104.

Kull, T. (1998). Fruit-set and recruitment in populations of Cypripedium calceolus L. in Estonia. Botanical Journal of the Linnean Society, 126, 27-38.

Kull, T. (1999). Cypripedium calceolus L. Journal of Ecology, 87, 913-924. DOI: 10.1046/j.1365-2745.1999.00407.x

Kull, T. (2003). Cypripedium calceolus L. - Interpretating population trends through short-term and long-term monitoring. In: T. Ryttäri, Ü. Kukk, T. Kull, A. Jäkäläniemi \& M. Reitalu (Eds.), Monitoring of threatened vascular plants in Estonia and Finland - methods and experiences (pp. 71-75). Vammalan Kirjapaino Oy, Vammala: Finnish Environment Institute.

Kull, T. \& Hutchings, M. J. (2006). A comparative analysis in decline in the distribution ranges of orchid species in Estonia and the United Kingdom. Biological Conservation, 129, 31-39. DOI: 10.1016/j.biocon.2005.09.046

Matysek, M., Binkiewicz, B. \& Wróbel, S. (2014). The first location of the yellow-flowered form of Lady's Slipper Cypripedium calceolus f. flavum in the Tatra National Park. Chronmy Przyrodę Ojczysta, 70(4), 358-361.

McCormick, M. K. \& Jacquemyn, H. (2014). What constrains the distribution of orchid populations? New Phytologist, 202, 392-400. DOI: $10.1111 / \mathrm{nph} .12639$

Michálková, D. (2007). Diversity of dry grasslands in the Považský Inovec Mts. (Slovakia) - a numerical analysis. Hacquetia, 6(1), 61-76. DOI: 10.2478/v10028-007-0002-z

Minasiewicz, J. \& Znaniecka, J. M. (2014). Characterization of 15 novel microsatellite loci for Cypripedium calceolus (Orchidaceae) using MiSeq sequencing. Conservation Genetics Resources, 6, 527-529. DOI: 10.1007/s12686-014-0170-3

Nicolè, F., Brzosko, E. \& Till-Bottraud, I. (2005). Population viability analysis of Cypripedium calceolus in a protected area: longevity, stability and persistence. Journal of Ecology, 93, 716-726. DOI: 10.1111/j.1365-2745.2005.01010.x

Nilsson, L. A. (1979). Anthecological studies on the Lady's Slipper, Cypripedium calceolus (Orchidaceae). Botaniska Notiser, 132, 329-347.

Oostermeijer, J. G. B, Luijten, S. H. \& den Nijs, J. C. M. (2003). Integrating demographic and genetic approaches in plant conservation. Biological Conservation, 113, 389-398. DOI: 10.1016/S0006-3207(03)00127-7

Pillon, Y. \& Chase, M. W. (2007). Taxonomic exaggeration and its effects on orchid conservation. Biological Conservation, 21, 263-265. DOI: 10.1111/j.1523-1739.2006.00573.x

Piwowarski, B. (2013). Nowe stanowisko obuwika pospolitego Cypripedium calceolus na Płaskowyżu Jędrzejowskim (Niecka Nidziańska). Chrońmy Przyrodę Ojczysta, 69(1), 74-77. (In Polish).

Puchnina, L. V. (2017). Status of Calypso bulbosa and Cypripedium calceolus (Orchidaceae) populations in the Pinega State Nature Reserve. Nature Conservation Research, 2(Suppl. 1), 125-150. DOI: 10.24189/ncr.2017.023

LANKESTERIANA 17(3). 2017. (C) Universidad de Costa Rica, 2017. 
Puchnina, L. V., Golovina, E. O., Filippov, D. A., Galanina, O. V., Makarova, M. A. \& Kucherov, I. B. (2015). Localities of rare and protected species of vascular plants in the Zvozsky designed Nature Park and its surroundings (Arkhangelsk region). Arctic Evironmental Research, 4, 100-110.

Randić, M., Brkljačić, A., Lukač, G. \& Kremer, D. (2013). New localities of rare NATURA 2000 species: Pulsatilla grandis Wender., Genista holopetala (Koch) Bald. and Cypripedium calceolus L. in the NW Dinarides in Croatia. Natura Croatica, 22(1), 95-109.

Rassi, P., Alanen, A., Kanerva, T. \& Mannerkoski, I. (Eds.) (2001). Suomen lajien uhanalaisuus 2000. Helsinki: Ympäristöministeriö \& Suomen ympäristökeskus. (In Finnish)

Shefferson, R. P., Kull, T., Tali, K. \& Kellett, K. M. (2012). Linking vegetative dormancy to fitness in two longlived herbaceous perennials. Ecosphere, 3(2), 13. DOI: 10.1890/ES11-00328.1

Silaeva, T. B. (Ed.) (2003). Red Data Book of the Republic of Mordovia: Rare species of plants, lichens and fungi. Saransk: Mordovia Book Publishing House. (In Russian).

Stavrovskaya, L. A. (1984). Ecological and biological features of Lady's Slipper in conditions of Berezino Reserve. Zapovedniki Belorussii, 8, 32-40. (In Russian)

Stetsuk, N. P. (2013). Biological features of Cypripedium calceolus L. in the territory of national park "Buzuluksky bor" (Buzuluk pine forest). Vestnik of Orenburg State Pedagogical University. Electronic Scientific Journal, 4(8), 38-43.

Tatarenko, I. V. (1996). Orchids of Russia: life forms, biology, strategy of preservation. Moscow: Argus. (In Russian).

The Plant List. (2013). Version 1.1. Retrieved 24 May 2017 from http://www.theplantlist.org/

Tremblay, R. L. (1994). Frequency and consequences of multi-parental pollinations in a population of Cypripedium calceolus var. pubescens (Orchidaceae). Lindleyana, 9(3), 161-167.

Tsyganov, D. N. (1983). Phytoindication of ecological regimes in the mixed coniferous-broad-leaved forest subzone. Moscow: Nauka. (In Russian).

Turis, P., Kliment, J., Feráková, V., Dítě, D., Eliáš, P., Hrivnák, R., Koštál, J., Šuvada, R., Mráz, P. \& Bernátová, D. (2014). Red List of vascular plants of the Carpathian part of Slovakia. Thaiszia - Journal of Botany, 24(1), 35-87.

Vakhrameeva, M. G. \& Tatarenko, I. V. (1998). Age structure of population of orchids with different life forms. Acta Universitatis Wratislaviensis, 2037, 129-139.

Vakhrameeva, M. G., Varlygina, T. I. \& Tatarenko, I. V. (2014). Orchids of Russia (biology, ecology and protection). Moscow: KMK Scientific Press Ltd. (In Russian).

Varlygina, T. I. (2011). Preservation of the Orchidaceae in Russia. In: I. I. Shamrov (Ed.), Protection and cultivation of orchids (pp. 76-80). Moscow: KMK Scientific Press Ltd. (In Russian).

Varlygina, T. I. \& Matsenko, A. E. (1986). Comparative characteristics of two Laddy's Slipper's coenopopulations in the Moscow region. In: “Conservation and cultovation of orchids”: Abstracts of the III All-Union Conference (pp. 24-25). Moscow: Nauka. (In Russian).

Witkowski, Z. J., Król, W. \& Solarz, W. (Eds.) (2003). Carpathian List of Endangered Species. Vienna \& Krakow: WWF and Institute of Nature Conservation, Polish Academy of Sciences.

Wotavova, K., Balounova, Z. \& Kindlmann, P. (2004). Factors affecting persistence of terrestrial orchids in wet meadows and implications for their conservation in a changing agricultural landscape. Biological Conservation, 118, $271-279$. DOI: 10.1016/j.biocon.2003.09.005

Yamashkin, A. A. (1998). Physical and geographical conditions and landscapes of the Republic Mordovia. Saransk: Publisher of the Mordovia State University. (In Russian).

Yamashkin, A. A. (Ed.) (2012). Geographical atlas of the Republic of Mordovia. Saransk: Publisher of the Mordovia State University. (In Russian).

Zheleznaya, E. (2015). Results of a study of Cypripedium in several regions of Siberia (Russia). European Journal of Environmental Sciences, 5(2), 134-141. DOI: 10.14712/23361964.2015.86 
LANKESTERIANA 